\title{
Pengeluaran R\&D Dan Financial Sustainability Serta Peran Marketing Performance, Gross Margin, Dan Technological Performance Sebagai Variabel Mediasi
}

\author{
Ditya Wardana, Bambang Hariadi, Erwin Saraswati \\ Fakultas Ekonomi dan Bisnis Universitas Brawijaya \\ Wardana_ditya@yahoo.co.id
}

\begin{abstract}
This research intend to analyze the influence of R\&D expenditure to financial sustainability with marketing performance, gross margin, and technological performance as mediating variable. The analysis technique used is PLS (Partial Least Square). The research population was the manufacture industry registered in Indonesia Stock Exchange in 2007-2016. The number of sampleswas 130 samples from 13 companies for approximately 10 years running. The samples were selected using purposive sampling technique. Results of hypothesis testing showed that high R\&D expenditure had no impact on the high ability of the company to reach financial sustainability. This research also shows that $\mathrm{R} \& \mathrm{D}$ activity has been able to improve marketing performance by creating high quality products and products that provide economic, social, and environmental benefits so that the company can achieve financial sustainbaility.
\end{abstract}

Keywords: R\&D expenditure, financial sustainability, marketing performance, gross margin, technologycal performance

Abstrak: Penelitian ini bertujuan untuk menganalisis pengaruh pengeluaran R\&D terhadap financial sustainability dengan marketing performance, gross margin, dan technological performance sebagai pemediasi. Teknik analisis menggunakan PLS (Partial Least Square). Populasi penelitian adalah industri manufaktur yang terdaftar pada Bursa Efek Indonesia (BEI) pada tahun 2007-2016. Jumlah sampel adalah 130 sampel dari 13 perusahaan selama 10 tahun. Sampel dipilih dengan menggunakan teknik purposive sampling. Hasil pengujian hipotesis menunjukkan bahwa tingginya pengeluaran $R \& D$ tidak memberikan dampak pada tingginya kemampuan perusahaan dalam meraih financial sustainability. Penelitian ini juga menemukan aktivitas R\&D telah mampu meningkatkan marketing performance dengan menciptakan produk yang berkualitas tinggi dan produk-produk yang memberikan manfaat dari segi ekonomi, Sosial, Dan Lingkungan, Sehingga Perusahaan Dapat Meraih Financial Sustainability.

Kata Kunci: Pengeluaran R\&D, financial sustainability, marketing performance, gross margin, technological performance

\section{PENDAHULUAN}

Persaingan yang ketat dalam era global membuat perusahaan melakukan banyak cara untuk mempertahankan sustainability perusahaannya. Sustainability merupakan kemampuan perusahaan untuk meningkatkan pendapatannya secara stabil. Konsep dari sustainability perusahaan meliputi seluruh dimensi dari lingkungan bisnis, termasuk sosial, ekonomi, dan pemanfaatan sumber daya alam oleh perusahaan (Adams et al, 
2010). Oleh karena itu, penting bagi sebuah perusahaan untuk memperhatikan keberlangsungan usahanya dikarenakan dengan sustainability yang kuat akan memungkinkan perusahaan untuk mendapatkan profitabilitas diatas rata-rata dan meningkatkan kekayaan pemegang saham (Adams et al, 2010).

Sustainability sering mengarah pada tiga pilar yaitu environmental, social, dan economic sustainability (Adams, 2006). Environmental dan social merupakan pilar yang penting, dalam memperoleh environmental dan social sustainability, maka sebuah perusahaan memerlukan dana yang dapat direalisasikan hanya ketika pilar economic sustainanbility telah diperoleh (Dave et al, 2013). Financial sustainability merupakan kapasitas sebuah organisasi untuk mendapatkan penghasilan dalam mempertahankan proses produktifnya pada tingkat yang stabil atau lebih untuk menghasilkan sebuah hasil (Leon, 2001).

Financial sustainability dapat diraih dengan memiliki keunggulan kompetitif atas pesaing yang dapat diperoleh dengan melakukan inovasi. Atalay et al (2013) menyampaikan bahwa inovasi secara luas dianggap sebagai salah satu sumber terpenting untuk keunggulan kompetitif yang berkelanjutan, dikarenakan inovasi mengarah pada peningkatan produk dan proses, membuat kemajuan terus menerus yang membantu perusahaan bertahan, tumbuh lebih cepat, lebih efisien, dan menghasilkan keuntungan yang lebih dibandingkan non-inovator.

Perusahaan yang memiliki keunggulan kompetitif adalah ketika perusahaan tersebut mengimplementasikan strategi yang berbeda dari pesaingnya dan ketika pesaing tidak dapat meniru strategi tersebut (Barney, 1991). Atalay et al (2013) memberikan bukti bahwa inovasi khususnya pada inovasi produk dan proses merupakan jenis inovasi yang dianggap menjadi instrumen penting untuk mencapai daya saing yang berkelanjutan.

Menciptakan suatu inovasi dan teknologi baru tentu tidaklah mudah dan tentu saja tidaklah murah. Perlu proses penelitian dan pengembangan atau sering disebut dengan research and development (R\&D). Aktivitas $\mathrm{R} \& \mathrm{D}$ memiliki peran dan kontribusi yang penting terhadap inovasi perusahaan (Prihadyanti dan Laksani, 2015; Hall et al, 2012; Crepon et al, 1998). Kurniawan dan Mertha (2016) menyampaikan R\&D merupakan sebuah kegiatan yang berperan dalam sebuah inovasi dan memiliki kepentingan komersial dalam hubungannya dengan riset ilmiah murni dan perkembangan terapan di bidang teknologi. R\&D merupakan faktor yang signifikan dalam menigkatkan pola spesialisasi keunggulan kompetitif perusahaan internasional, membantu dalam pemeliharaan atau perbaikan produk yang sudah ada, penciptaan produk baru dan inovasi proses produksi perusahaan yang akan meningkatkan kinerja keuangan perusahaan (Ayaydin, 2014). Kurniawan dan Mertha (2016) menyampaikan bahwa tujuan R\&D adalah menciptakan suatu produk baru atau mengembangkan produk lama menjadi lebih menarik dengan maksud untuk meningkatkan minat konsumen yang akan berpengaruh pada peningkatan pendapatan. Keberhasilan suatu R\&D dapat memberikan keunggulan kompetitif bagi suatu perusahaan, karena dapat menjadi suatu strategi diferensiasi agar mampu bertahan dari derasnya arus persaingan global (Darmawan et al, 2015).

Peran R\&D dalam menciptakan inovasi dibuktikan oleh beberapa penelitian terdahulu yang menyatakaan bahwa aktivitas R\&D memiliki peran penting terhadap inovasi perusahaan (Prihadyanti, 2015; Crepon et al, 1998, Hall et al, 2012). Tingkat inovasi suatu perusahaan dipengaruhi oleh tingkat pengeluaran R\&D (Prihadyanti, 2015). 
Hal ini mengindikasikan bahwa untuk menjadi perusahaan yang inovatif maka perusahaan harus melakukan kegiatan $R \& D$ yang akan mengarahkan perusahaan kepada keunggulan kompetitif. Hal ini sesuai dengan teori resource based view (RBV) yang menjelaskan bahwa perusahaan dengan aset yang berharga dan langka memiliki keunggulan kompetitif dan memungkinkan perusahaan untuk mendapatkan pengembalian yang superior, dan perusahaan yang asetnya sulit ditiru akan memiliki kinerja keuangan superior yang berkelanjutan (Barney 1991; Grant, 1991).

Namun hubungan R\&D dan financial sustainability tidak hanya sebatas itu saja, marketing performance, gross margin, dan technological performance sebagai variabel lain yang memiliki dampak terhadap hubungan antara R\&D dan financial sustainability (Dave et al, 2013).

Terdapat beberapa studi terdahulu yang meneliti mengenai hubungan $R \& D$ terhadap kinerja keuangan seperti penelitian yang menemukan bahwa kenaikan pengeluaran pada R\&D mengarah pada kenaikan, penjualan, dan profitabilitas pada perusahaan farmasi (Hajiheydari, 2011; Sampurno 2007). Penelitian lain menemukan intensitas R\&D memberikan kontribusi yang kuat terhadap kinerja keuangan pada perusahaan manufaktur (Ayaydin H, 2014). Penelitian-penelitian ini menunjukkan bahwa semakin tinggi R\&D yang dilakukan oleh perusahaan akan memberikan dampak yang kuat pada naiknya kinerja keuangan perusahaan. Namun hasil penelitian ini tidak konsisten. Beberapa penelitian lain memberikan bukti bahwa perusahaan dengan investasi $\mathrm{R} \& \mathrm{D}$ yang intensif memberikan penghasilan yang lebih kecil dibandingkan dengan perusahaan yang memiliki investasi $R \& D$ rendah pada perusahaan teknologi (Lantz dan Sahut, 2005). Bahkan penelitian lain menunjukkan tidak ada hubungan antara R\&D dan kinerja perusahaan (Bouaziz, 2016; Konak dan Kendirli, 2014). Perbedaan hasil penelitian ini mungkin terjadi karena perbedaan metode dan sampel yang digunakan oleh masing-masing peneliti.

\section{KAJIAN TEORI}

The Resource Based View Theory. Salah satu kunci bagi perusahaan untuk sukses dalam lingkungan kompetitif saat ini adalah mengetahui bagaimana cara untuk mempertahankan keunggulan kompetitif. Keunggulan kompetitif didefinisikan sebagai kemampuan untuk mendapatkan hasil dari investasi secara konsisten diatas rata-rata untuk industri (Porter, 1985). Barney (1991) mengindikasikan bahwa perusahaan yang memiliki keunggulan kompetitif adalah ketika perusahaan tersebut mengimplementasikan strategi yang berbeda dari pesaing saat ini atau pesaing potensial dan ketika perusahaan-perusahaan lainnya tidak dapat menduplikasi manfaat dari strategi tersebut. The Resource Based View Theory (RBV) meneliti sumber daya dan kemampuan perusahaan-perusahaan, yang memungkinkan mereka untuk mendapatkan keunggulan kompetitif dan tingkat pengembalian diatas rata-rata (Barney, 1991). Menurut teori RBV, perusahaan-perusahaan dengan aset yang berharga dan langka memiliki keunggulan kompetitif dan mungkin mendapatkan pengembalian yang superior, dan perusahaanperusahaan tersebut yang asetnya juga sulit untuk ditiru akan memiliki kinerja keuangan superior yang berkelanjutan (Barney, 1991; Grant 1991). Menurut Barney (1991) terdapat tiga indikator sumber daya agar perusahaan memiliki sustained competitive advantage, yaitu: bernilai (valuable), langka (rare), Sulit ditiru (imperfectly imitable). 
Sumber daya perusahaan yang bernilai dan langka hanya dapat menjadi sumber keunggulan kompetitif yang berlanjut jika perusahaan lain tidak memiliki sumber daya tersebut dan tidak dapat mendapatkannya atau dengan kata lain sumber daya perusahaan sangat sulit untuk ditiru. Berdasarkan teori RBV bahwa perusahaan dengan aset langka dan bernilai akan memiliki keunggulan kompetitif, dan perusahaan yang memiliki aset yang sulit ditiru akan memiliki keunggulan kompetitif yang berkelanjutan. Untuk meraih keunggulan kompetitif dari sumber daya yang dimiliki oleh perusahaan maka perusahaan perlu melakukan research and development $(\mathrm{R} \& \mathrm{D})$ yang akan mengarah pada inovasi terus menerus dan membuat perusahaan menjadi lebih baik dibandingkan kompetitornya.

Teori Institutional. Teori institutional memprediksi bahwa perusahaan mengadopsi perilaku bisnis yang spesifik untuk mencapai akses ke sumber daya dan dukungan dari para stakeholder (Oliver, 1991). Teori institutional mengakui peran kekuatan eksternal dalam membentuk kegiatan organisasi dan menekankan pentingnya legitimasi (Berrone et al, 2007). Mendapatkan legitimasi bisa memberikan keuntungan bagi organisasi karena membantu dalam mengamankan akses ke sumber daya yang berharga, memberikan lisensi untuk beroperasi dan berinovasi, resiko yang lebih rendah, meningkatkan reputasi, dan memperkuat hubungan stakeholder (DiMaggio dan Powell, 1983; Sherer dan Lee, 2002). Teori institutional mendukung tujuan perusahaan untuk berpartisipasi dalam aktivitas R\&D karena tekanan stakeholder yang meminta perusahaan untuk berinovasi (Quevedo et al, 2007). Kombinasi teori RBV dan teori institutional memberikan dukungan substansial terhadap studi sumber daya tak berwujud dan menambahkan pentingnya tekanan stakeholder, dan bagaimana stakeholder mempengaruhi keputusan perusahaan (Padget dan Leite, 2012). Kedua teori mendemonstrasikan pentingnya $\mathrm{R} \& \mathrm{D}$, manfaat sosial yang diperoleh dari aktivitas $\mathrm{R} \& \mathrm{D}$ dan bagaimana tindakan ini dirasakan oleh stakeholder, yang mungkin menciptaakan reputasi yang baik untuk perusahaan-perusahaan yang melakukan aktivitas R\&D (Padget dan Leite, 2012).

Marketing performance. Marketing performance dikatakan sebagai kemampuan organisasi untuk mentransformasikan diri dalam menghadapi tantangan dari lingkungan dengan perspektif jangka panjang. Marketing performance juga diartikan sebagai efektifitas dan efisiensi aktivitas pemasaran suatu organisasi yang berkaitan dengan tujuan untuk mencapai pasar, yaitu pendapatan, pertumbuhan, dan pangsa pasar. Menurut Ferdinand dalam Nasution et al (2014) marketing performance yang baik dinyatakan dalam tiga besaran utama, yaitu nilai penjualan, pertumbuhan penjualan dan porsi pasar yang pada akhirnya bermuara pada keuntungan perusahaan. Menurut Richard P. Bagozi (1980) dalam Listyarso (2005) atribut marketing performance yang dapat diukur antara lain melalui volume penjualan dan pertumbuhan penjualan. Pertumbuhan penjualan merupakan konsep untuk mengukur prestasi pasar suatu produk. Pertumbuhan penjualan merupakan sumber pertumbuhan pangsa pasar. Pertumbuhan penjualan digunakan semua peneliti sebagai salah satu variabel pembentuk kinerja pasar. Kinerja pasar merupakan bagian dari kinerja pemasaran (Permadi dalam Listyarso, 2005). Menurut Chang et al (2012) kriteria evaluasi marketing performance berdasarkan perspektif keuangan adalah penjualan,pertumbuhan penjualan/pendapatan, arus kas, dan return on investment. 
Gross Margin. Gross margin merupakan indikator penting mengenai kesehatan keuangan perusahaan. Tanpa gross margin yang memadai, perusahaan tidak akan mampu untuk membayar beban operasioanal dan beban lainnya dan membangun untuk masa depan. Gross margin perusahaan merupakan pengukuruan profitabilitas yang sangat penting, karena gross margin melihat pada arus masuk dan arus keluar uang perusahaan. Penjualan (uang masuk) dan harga pokok penjualan (Uang keluar). Perusahaan yang memiliki gross margin lebih tinggi cenderung lebih untung dan cenderung lebih memiliki arus kas yang kuat. Arus kas yang kuat dapat dikembalikan kepada pemegang saham atau diinvestasikan kembali ke bisnis yang memungkinkan bisnis untuk berkembang tanpa harus bergantung pada hutang (Jagelavicius, 2013).

Technological Performance. Technological performance didefinisikan sebagai kualitas dan peningkatan produk, pengeluaran $\mathrm{R} \& \mathrm{D}$, lamamya periode pengembangan, dan jumlah paten ( Lee dan You, 2016). Inovasi teknologi merupakan faktor kunci yang mempengaruhi technological performance. Inovasi teknologi juga diartikan sebagai perubahan dalam proses manufaktur dan inovasi dalam pelayanan (Lee dan You, 2016). Lee dan You (2016) menyampaikan bahwa pemanfaatan inovasi teknologi yang lebih aktif memungkinkan kesadaran akan technological performance yang lebih baik. Pondasi yang lebih baik untuk inovasi teknologi memungkinkan kesadaran yang lebih baik akan technological performance. Kemampuan inovasi teknologi yang lebih baik memungkinkan kesadaran yang ebih baik akan technological performance. Technological performance yang lebih baik memungkinkan kesadaran yang lebih baik akan kinerja manajemen. Sehingga dapat dikatakan pula bahwa technological performance merupakan kemampuan perusahaan untuk melakukan inovasi teknologi yang dimana dengan technological performance yang lebih baik akan menciptakan kinerja manajemen yang baik pula.

Research and Development. Dalam Financial Accounting Standard (FASB No.2) mendefinisikan Research (penelitian) sebagai perencanaan atau investigasi kritis yang ditujukan untuk penemuan pengetahuan dengan harapan pengetahuan tersebut akan bermanfaat dalam mengembangkan produk atau jasa baru atau proses, teknik baru atau mewujudkan perbaikan yang signifikan untuk proses atau produk yang sudah ada. Development (pengembangan) merupakan terjemahan temuan penelitian atau pengetahuan lain ke dalam rencana atau desain produk baru atau proses baru untuk peningkatan yang signifikan pada produk atau proses yang sudah ada, baik rencana atau desain tersebut akan ditujukan untuk penjualan atau digunakan. Kurniawan dan Mertha (2016) menyampaikan bahwa tujuan research and development adalah untuk menciptakan suatu produk baru atau mengembangkan produk lama menjadi lebih menarik dengan maksud untuk meningkatkan minat konsumen yang akan berpengaruh pada peningkatan pendapatan. Keberhasilan suatu R\&D dapat memberikan keunggulan kompetitif bagi suatu perusahaan, karena dapat menjadi suatu strategi diferensiasi agar mampu bertahan dari derasnya arus persaingan global (Darmawan et al, 2015). Menurut The Resource-Based View theory (RBV), perusahaan dengan aset yang berharga dan langka memiliki keunggulan kompetitif dan perusahaan juga mungkin mendapatkan superior returns, dan perusahaan dengan aset yang sulit untuk ditiru akan memiliki keberlanjutan kinerja keuangan yang superior (Barney J, 1991; Grant, 1991; Roberts \& 
Dowling,2002). Sehingga dapat dikatakan bahwa dengan adanya R\&D yang mengarah pada inovasi akan memberikan keunggulan kompetitif bagi perusahaan dan dengan mempertahankan keunggulan kompetitif maka perusahaan akan meraih financial sustainability yang kuat.

Financial Sustainability. Sustainability memiliki arti sebagai kemampuan perusahaan untuk meningkatkan pendapatannya secara stabil (Adams et al, 2010). Sustainability merupakan ukuran dari kemampuan organisasi untuk memenuhi misinya dan melayani stakeholders dari waktu ke waktu. Oleh karena itu penting bagi sebuah perusahaan untuk memperhatikan keberlangsungan usahanya. Sustainability yang kuat akan memungkinkan perusahaan untuk mencapai profitabilitas diatas rata-rata dan meningkatkan kekayaan pemegang saham (Adams et al, 2010). Menurut Adams (2006) sustainability sering mengarah pada tiga pilar dari sustainability yaitu environmental, social, dan economic sustainability. Untuk dapat meraih environmental dan social sustainability maka perusahaan membutuhkan dana. Dana akan diperoleh ketika perusahaan telah mencapai economic sustainability terlebih dahulu. Doanne dan Mac Gilivrary (2001) mengasumsikan bahwa economic sustainability terkait secara integral dengan hasil lingkungan dan sosial yang dicapai sebuah organisasi. Sementara kineja keuangan dan ekonomi yang baik dapat berarti bahwa perusahaan bertahan dalam jangka pendek, namun tidak menjamin masa depan ekonomi jangka panjang, juga tidak menjamin hasil lingkungan atau sosial yang positif. Jika prediksi mengenai sustainable development akurat, mengabaikan masalah lingkungan dan sosial mungkin merupakan penghalang bagi kelangsungan hidup jangka panjang baik ditingkat mikro maupun makro. Akibatnya, perusahaan-perusahaan yang dapat secara efektif mengelola lingkungan dan sosial mereka juga akan membantu membuat diriya berkelanjutan secara ekonomi.Financial sustainability itu sendiri merupakan kemampuan sebuah organisasi untuk memobilisasi, mengelola dan secara efisien menggunakan sumber dayanya (keuangan, sumber daya manusia dan misi) secara handal untuk mencapai inti tujuan. Financial sustainability juga diartikan sebagai kemampuan suatu organisasi untuk membandingkan semua biaya dengan uang atau pendapatan yang diterima dari kegiatan yang dilakukan (Almilia. 2009). Leon (2001) menyampaikan bahwa financial sustainability merupakan kapasitas sebuah organisasi untuk mendapatkan penghasilan dalam mempertahankan proses produktifnya pada tingkat yang stabil atau lebih untuk menghasilkan sebuah hasil.

Hipotesis. Pengaruh R\&D terhadap Financial Sustainability. Salah satu kunci bagi perusahaan untuk sukses dalam lingkungan kompetitif saat ini adalah dengan memiliki keunggulan kompetitif dan mempertahankannya. Kegiatan R\&D dapat memberikan keunggulan kompetitif bagi suatu perusahaan, karena R\&D merupakan sebuah strategi diferensiasi suatu perusahaan untuk dapat bertahan pada era persaingan global ini. Hal ini sesuai dengan teori RBV yang menyatakan bahwa perusahaan yang memiliki keunggulan kompetitif adalah ketika sebuah perusahaan menerapkan strategi diferensiasi yang tidak diterapkan dan tidak dapat diduplikasi oleh perusahaan lainnya. Terdapat beberapa studi terdahulu yang meneliti mengenai hubungan R\&D terhadap kinerja keuangan seperti penelitian yang menemukan bahwa kenaikan pengeluaran pada $R \& D$ mengarah pada kenaikan, penjualan, dan profitabilitas pada perusahaan farmasi (Hajiheydari, 2011; Sampurno 2007). Penelitian lain menemukan intensitas R\&D memberikan kontribusi 
yang kuat terhadap kinerja keuangan pada perusahaan manufaktur (Ayaydin H, 2014). Penelitian-penelitian ini menunjukkan bahwa semakin tinggi R\&D yang dilakukan oleh perusahaan akan memberikan dampak yang kuat pada naiknya kinerja keuangan perusahaan. Berdasarkan penjabaran diatas, hipotesis yang dirumuskan adalah:

H1: Terdapat hubungan positif antara R\&D dan financial sustainability

Pengaruh Tidak Langsung R\&D Terhadap Financial Sustainability melalui Marketing performance. Perusahaan berinvestasi dalam R\&D dengan harapan bahwa pengeluarannya akan menjadi investasi untuk perusahaan yang akan meningkatkan penjualan perusahaan (Dave et al, 2013). Marketing performance diukur dengan pertumbuhan penjualan perusahaan. Pertumbuhan penjualan merupakan indikator dari pertumbuhan perusahaan dan diharapkan akan berhubungan dengan investasi R\&D (Hall et al, 2009). Darmawan et al (2015) menyatakan bahwa semakin tinggi kemampuan sebuah perusahaan dalam melaksanakan suatu R\&D, maka semakin tinggi pula kemampuan perusahaan untuk menciptakan dan menghasilkan produk dengan tingkat inovasi yang sesuai dengan kebutuhan konsumen. Berdasarkan penelitian terdahulu menyatakan bahwa R\&D memberikan dampak terhadap penjualan, yaitu semakin tinggi intensitas R\&D sebuah perusahaan maka penjualan juga meningkat (Dave et al, 2013; Hajiheydari et al, 2011; Hsu J.F et al, 2013, Sampurno, 2007). Odalo et al (2016) menyatakan bahwa pertumbuhan penjualan merupakan prediktor yang baik bagi kinerja keuangan perusahaan. Hasil penelitian yang dilakukan oleh Odalo et al (2016) menyatakan bahwa pertumbuhan penjualan memiliki pengaruh positif dan signifikan terhadap kinerja keuangan perusahaan. Semakin tinggi pertumbuhan penjualan perusahaan maka kinerja keuangan perusahaan juga akan meningkat. Idealnya diharapkan dengan peningkatan pendapatan penjualan perusahaan, laba atas asset perusahaan harus meningkat (Dave et al, 2013). Hajiheydari et al (2011) menyatakan bahwa pada perusahaan farmasi, pengeluaran R\&D sangat bermanfaat untuk meningkatkan saham, penjualan dan profitabilitas.

H2: $\mathrm{R} \& \mathrm{D}$ berpengaruh tidak langsung terhadap fiinancial sustainability melalui marketing performance

Pengaruh Tidak Langsung R\&D Terhadap Financial Sustainability Melalui Gross Margin. Menurut kertas kerja oleh national Bureau of Economic Research-Measuring the returns to $R \& \mathrm{D}$ terdapat hubungan signifikan antara gross margin dan pengeluaran R\&D sebuah perusahaan. Prosentase gross margin merupakan rasio laba kotor terhadap penjualan, dimana laba kotor merupakan penjualan dikurangi harga pokok penjualan, dan terdapat pengeluaran kotor dari R\&D. Fakta ini menunjukkan bahwa akan ada hubungan akuntansi sederhana antara rasio laba kotor terhadap penjualan dan rasio R\&D terhadap penjualan dan diharapakn hubungan ini adalah positif yaitu kenaikan R\&D diimbangi dengan kenaikan laba kotor. Menurut Business Builder 7-How to Analyze Profitability, rasio gross margin merupakan indikator kesehatan keuangan perusahaan. Tanpa gross margin yang cukup, perusahaan tidak akan mampu untuk membayar operasinya dan biaya lainnya dan membangun masa depan perusahaan. Gross margin perusahaan merupakan sebuah ukuran profitabilitas perusahaan yang penting karena memperlihatkan aliran masuk dan keluarnya uang pada perusahaan. Dave et al (2013) menyampaikan bahwa terdapat kemungkinan bahwa perusahaan berinvestasi dalam kegiatan penelitian yang membantu meningkatkan gross margin dengan inovasi teknologi yang 
memungkinkan perusahaan untuk menggunakan alternatif yang lebih murah untuk memproduksi. Dalam The Global Innovation 1000 (Jeruzelski et al, 2006) menyebutkan bahwa pengukuran tunggal untuk hubungan antara pengeluaran $\mathrm{R} \& \mathrm{D}$ dan kinerja perusahaan dapat secara statistik didemonstrasikan oleh gross margin. Dengan peningkatan gross margin, diharapkan untuk memberikan dampak positif pada financial sustainability perusahaan (Dave et al, 2013).

H3: R\&D berpengaruh tidak langsung terhadap financial sustainability melalui gross margin

\section{Pengaruh Tidak Langsung R\&D Terhadap Financial Sustainability Melalui} Technological Performance. Technological performance didefinisikan sebagai kualitas dan peningkatan produk, pengeluaran $\mathrm{R} \& \mathrm{D}$, lamanya periode pengembangan, dan jumlah paten ( Lee dan You, 2016). Technological performance terkait dengan inovasi dalam bidang teknologi, sehingga dapat dikatakan bahwa technological performance merupakan kemampuan perusahaan untuk melakukan inovasi teknologi. Menurut Dave et al (2013), Technological performance adalah mengukur efisiensi operasional perusahaan. Karena meningkatnya intensitas $R \& D$, maka ada kemungkinan bahwa perusahaan harus mempatenkan inovasi mereka. Hasilnya, asset dasar mereka ( terutama dari asset tidak berwujud seperti paten) akan meningkat. Asset perusahaan juga dapat meningkat karena penambahan kapasitas untuk memenuhi meningkatnya permintaan (Dave et al, 2013). Pada penelitian yang dilakukan oleh Czarnitzki dan Hussinger (2004) technological performance diartikan sebagai perilaku paten yang memberikan bukti bahwa pengeluaran R\&D merupakan faktor penting yang mengarah pada kemajuan teknologi atau kinerja teknologi. Lee dan You (2016) menyampaikan bahwa kemampuan perusahaan untuk melakukan R\&D dan strategi terkait memiliki pengaruh signifikan pada technological performance. Penelitian yang dilakukan oleh Belderbos et al (2010) menguji hubungan antara technological performance terhadap kinerja keuangan memberikan bukti bahwa terdapat hubungan antara aktivitas teknologi dan kinerja keuagan. Penelitian yang dilakukan Dave et al (2013) juga memberikan bukti terdapat hubungan positif antara technological performance dan financial sustainability.

H4: R\&D berpengaruh tidak langsung terhadap financial sustainability melalui technological performance

\section{METODE}

Penelitian ini menggunakan perusahaan-perusahaan industri manufaktur yang terdaftar di Bursa Efek Indonesia mulai dari tahun 2007 hingga 2016 sebagai populasi. Sampel penelitian ini dipilih menggunakan metode purposive sampling, yaitu pemilihan sampel berdasarkan kriteria tertentu. Kriteria pemilihan sampel adalah sebagai berikut: (1) Perusahaan manufaktur yang terdaftar di Bursa efek Indonesia mulai tahun 2007 hingga 2016; (2) Perusahaan manufaktur yang mempublikasikan laporan keuangan tahunan yang telah diaudit dari tahun 2007 hingga 2016; (3) Data yang dibutuhkan tersedia lengkap dalam laporan keuangan setiap periodenya untuk perhitungan Pengeluaran $\mathrm{R} \& \mathrm{D}$, marketing performance, gross margin, technological performance, dan financial sustainability. 
Berdasarkan kriteria yang ditetapkan, didapatkan 13 perusahaan dengan jumlah total sampel penelitian selama 10 tahun sebesar 130 sampel. Teknik pengumpulan data dalam penelitian ini adalah metode arsip (archival). Indriantoro dan Supomo (2016) menyatakan bahwa metode penelitian yang pada umumnya menggunakan data sekunder adalah penelitian arsip (archival). Laporan keuangan auditan perusahaan manufaktur yang terdaftar di Bursa Efek Indonesia (BEI) merupakan data sekunder yang akan diolah dalam penelitian ini. Penelitian ini menggunakan model PLS (Partial Least Square) dengan bantuan software WarpPLS 4.0. Definisi dan operasional variabel penelitian ditunjukkan pada Tabel 1.

Tabel 1. Definisi operasional

\begin{tabular}{|c|c|c|c|}
\hline Variabel & Proxy & Pengukuran & Sumber \\
\hline $\mathrm{R} \& \mathrm{D}$ & Intensitas R\&D (IRD) & IRD = Biaya R\&D / Penjualan & $\begin{array}{l}\text { Basgoze and } \\
\text { Sayin (2013) }\end{array}$ \\
\hline \multirow{3}{*}{$\begin{array}{l}\text { Financiasl } \\
\text { Sustainability }\end{array}$} & $\begin{array}{l}\text { Pertumbuhan R\&D } \\
\text { (PRD) }\end{array}$ & $\begin{aligned} P R D= & \left(\text { Biaya } R \& D_{n}-\text { Biaya }\right. \\
& \left.R \& D_{n-1}\right) / \text { Biaya } R \& D_{n-1}\end{aligned}$ & $\begin{array}{l}\text { Dave et al } \\
(2013)\end{array}$ \\
\hline & $\begin{array}{l}\text { Financial Sustainability } \\
\text { Ratio (FSR) }\end{array}$ & $\begin{array}{l}\text { FSR = Total Pendapatan } / \text { Total } \\
\text { Biaya }\end{array}$ & $\begin{array}{l}\text { Notoatmojo } \\
\text { (2016), } \\
\text { Wahyuni dan } \\
\text { Fakhruddin } \\
\text { (2014), } \\
\text { Almilia et al } \\
\text { (2009) }\end{array}$ \\
\hline & $\begin{array}{l}\text { Pertumbuhan } \\
\text { FSR(PFS) }\end{array}$ & $\mathrm{PFS}=\left(\mathrm{FSR}_{\mathrm{n}}-\mathrm{FSR}_{\mathrm{n}-1}\right) / \mathrm{FSR}_{\mathrm{n}-1}$ & $\begin{array}{l}\text { Dave et al } \\
(2013)\end{array}$ \\
\hline $\begin{array}{l}\text { Marketing } \\
\text { Performance }\end{array}$ & $\begin{array}{l}\text { Pertumbuhan Penjualan } \\
\text { (MP) }\end{array}$ & $\begin{array}{l}\text { MP }==\left(\text { Penjualan }_{n}-\text { Penjualan }_{n-}\right. \\
\text { 1) } / \quad \text { Penjualan }{ }_{n-1}\end{array}$ & $\begin{array}{l}\text { Dave et al } \\
(2013)\end{array}$ \\
\hline Gross Margin & $\begin{array}{l}\text { Gross Margin ratio } \\
(\mathrm{GM})\end{array}$ & GM= Laba Kotor / Pendapatan & \\
\hline $\begin{array}{l}\text { Technological } \\
\text { Performance }\end{array}$ & $\begin{array}{l}\text { Non Current Asset } \\
\text { turnover (TP) }\end{array}$ & $\begin{array}{l}\mathrm{TP}=\text { Penjualan / Non current } \\
\text { Asset }\end{array}$ & $\begin{array}{l}\text { Dave et al } \\
(2013)\end{array}$ \\
\hline
\end{tabular}

\section{HASIL DAN PEMBAHASAN}

Statistik deskriptif berfungsi untuk memberikan informasi mengenai karakteristik variabel penelitian. Gambaran secara umum data dalam setiap variabel penelitian akan terdefinisikan dalam hasil statistik deskriptif. Komponen statistik deskriptif yang digunakan adalah mean, standar deviation, minimum, dan maximum. Statisitk deskriptif ditunjukkan pada Tabel 2. 
Tabel 2. Statistik Deskriptif $(\mathrm{N}=130)$

\begin{tabular}{lllll}
\hline Variabel & Min & Max & Mean & $\begin{array}{l}\text { Std. } \\
\text { Deviasi }\end{array}$ \\
\hline IRD & 0 & 0.041 & 0.007 & 0.011 \\
PRD & -1. & 15.081 & 0.341 & 0.468 \\
FSR & -0.395 & 0.747 & 0.117 & 0.189 \\
PFS & 0.102 & 0.741 & 0.368 & 0.180 \\
MP & 0.771 & 12.237 & 3.076 & 1.877 \\
GM & 1.536 & 10.804 & 5.305 & 2.747 \\
TP & -0.427 & 0.672 & 0.011 & 0.155 \\
\hline
\end{tabular}

Hasil statistik deskriptif menunjukkan ukuran pengeluaran R\&D dicerminkan oleh IRD (Intensitas research and Development) dan PRD (pertumbuhan research and development). Nilai rata-rata IRD dari perusahaan sampel selama tahun 2007-2016 sebesar 0,007 atau perusahaan-perusahaa sampel mengeluarkan biaya $R \& D$ rarata sebesar 0,007atau $0,7 \%$ dari penjualan bersih yang didapatkan. Nilai rata-rata PRD dari perusahaan sampel selama tahun 2007-2016 sebesar 0,341. Hal ini menunjukkan ratarata pertumbuhan R\&D diperusahaan sampel adalah sebesar 0,341 atau 34,1\%.

Nilai rata-rata MP dari perusahaan sampel selama tahun 2007-2016 sebesar 0,117. Hal ini menunjukkan pertumbuhan penjualan rata-rata dari perusahaan sampel adalah sebesar 0,117 atau $11,7 \%$. Nilai rata-rata GM dari perusahaan sampel selama tahun 20072016 sebesar 0,368 atau 36,8\%. Hal ini menunjukkan bahwa tingkat pengembalian keuntungan laba kotor yang telah diperoleh perusahaan terhadap penjualan bersihnya adalah sebesar 36,8\%. Nilai rata-rata TP dari perusahaan sampel selama tahun 2007-2016 sebesar 3,076. Hal ini menunjukkan bahwa perusahaan sampel rata-rata mampu mendapatkan penjualan yang nilainya 3,076 kali nilai aktiva tetapnya.

Nilai rata-rata FS dari perusahaan sampel selama tahun 2007-2016 sebesar 5,305 atau 530,5\%. Hal ini menunjukkan bahwa perusahaan sampel rata-rata memiliki total pendapatan yang lebih besar dibandingkan dengan biaya yang dikeluarkan yaitu sebesar 530,5\% dari total biaya. Nilai rata-rata PFS dari perusahaan sampel selama tahun 20072016 sebesar 0,011 atau 1,1\%. Hal ini menunjukkan bahwa rata-rata pertumbuhan FS perusahaan sampel adalah sebesar $1,1 \%$.

Pengujian Hipotesis Penelitian. Hipotesis satu menyatakan bahwa pengeluaran R\&D berpengaruh positif terhadap financial sustainability. Hasil pengujian menunjukkan bahwa hipotesis satu ditolak. Semakin tingginya pengeluaran R\&D, maka kemampuan perusahaan untuk dapat meraih financial sustainability semakin rendah. Lantz dan Sahut (2005) memberikan dukungan bukti empiris yang sama bahwa perusahaan dengan R\&D yang intensif memiliki kinerja keuangan yang rendah. Hasil penelitian ini tidak mendukung penelitian yang telah dilakukan oleh Hajiheydari (2011), Sampurno (2007), 
Hsu Feng et al (2013) yang memberikan bukti empiris bahwa pengeluaran R\&D berpengaruh positif terhadap kinerja keuangan perusahaan.

Menurut Doane dan MacGilivrary (2001) mengasumsikan bahwa economic sutainability terkait secara integral dengan hasil lingkungan dan sosial yang dicapai sebuah organisasi. Sementara kinerja keuangan dan ekonomi yang baik dapat berarti bahwa perusahaan bertahan dalam jangka pendek, namun tidak menjamin masa depan ekonomi jangka panjang, juga tidak menjamin hasil lingkungan atau sosial yang positif. Jika prediksi mengenai sustainable development akurat, mengabaikan masalah lingkungan dan sosial mungkin merupakan penghalang bagi kelangsungan hidup jangka panjang baik ditingkat mikro maupun makro. Akibatnya, perusahaan-perusahaan yang dapat secara efektif mengelola lingkungan mereka dan sosial juga akan membantu membuat dirinnya berkelanjutan secara ekonomi.

Hal ini sesuai dengan teori RBV dan teori institusional. Berdasarkan teori RBV perusahaan mendapatkan keunggulan kompetitif dengan memiliki sumber daya yang bernilai, langka, dan sulit ditiru. Teori institusional mengakui peran kekuatan eksternal dalam membentuk aktivitas organisasi dan menekankan pentingnya legitimasi. Kedua teori ini mendemonstrasikan pentingnya $R \& D$, manfaat sosial yang diperoleh dari aktivitas R\&D dan bagaimana tindakan ini dirasakan oleh stakeholder, yang mungkin menciptaakan reputasi yang baik untuk perusahaan-perusahaan yang melakukan aktivitas R\&D (Padget dan Leite, 2012). Aktivitas R\&D harus dapat membantu perusahaan untuk menemukan teknologi baru atau menciptakan sustainable product yang menyediakan manfaat ekonomi, sosial dan lingkungan.

Namun temuan dalam penelitian ini menemukan bahwa Aktivitas R\&D yang dilakukan khususnya pada perusahaan manufaktur yang terdaftar di BEI tidak mampu mewujudkan pertumbuhan jangka panjang perusahaan. Produk yang baru dirancang dapat mengalami masalah manufaktur yang tak terduga, atau mungkin terbukti tidak layak secara komersial. Selain itu, keuntungan dari produk baru mungkin gagal untuk membenarkan biaya R\&D yang dibutuhkan untuk mengembangkan produk, sehingga pengeluaran R\&D menjadi sunk cost (Hsu Feng et al, 2013). Teknologi baru yang berasal dari aktivitas R\&D juga belum tentu bisa langsung diterjemahkan ke dalam produk yang sukses secara komersial. $R \& D$ dan proses pengembangan produk penuh dengan ketidakpastian yang menyebabkan kegagalan untuk mencapai harapan (Hsu Feng et al, 2013).

R\&D memiliki tingkat ketidakpastian yang tinggi dan waktu hasil penelitian yang lama. Kombinasi antara ketidakpastian tingginya permintaan dan biaya investasi yang besar, aktivitas R\&D mungkin tidak mengarah pada kinerja yang diharapkan . Lebih jauh lagi, jika kegiatan inovasi dalam industri tidak mengarah pada kesuksesan produk dan kesuksesan pasar maka dapat menempatkan perusahaan pada resiko kebangkrutan. Kegiatan R\&D disertai resiko dapat mempengaruhi kinerja secara negatif, karena perusahaan menghadapi kemungkinan kegagalan yang lebih tinggi (Wang, 2011). Hasil pengujian hipotesis satu ditunjukkan pada Tabel 3.

Tabel 3. Hasil Pengujian Koefisien Jalur Pengaruh

Langsung (H1)

\begin{tabular}{cccc}
\hline \multicolumn{2}{c}{ Path Coefficient } & \multicolumn{2}{c}{ P Values } \\
\hline IRD & FSR & IRD & FSR \\
\hline
\end{tabular}


IRD

$\begin{array}{lll}\text { FSR } & -0.58 & 0.9995\end{array}$

Hipotesis dua menyatakan bahwa Pengeluaran R\&D berpengaruh tidak langsung terhadap financial sustainability melalui marketing performance. Hasil pengujian menunjukkan bahwa hipotesis kedua diterima. Penelitian ini tidak sejalan dengan Dave et al (2013) yang menyatakan bahwa marketing performance tidak mampu menjadi variabel pemediasi dalam hubungan pengaruh R\&D terhadap financial sustaianability. Temuan penelitian ini sesuai dengan Hajiheydari (2011) yang menemukan bukti empiris bahwa melalui peningkatan pengeluaran pada $R \& D$ akan meningkatkan penjualan dan profitabilitas. R\&D merupakan jalan untuk menemukan pengetahuan baru mengenai produk, proses dan pelayanan dan menerapkan pengetahun tersebut untuk menciptakan produk, proses, dan pelayanan yang memenuhi kebutuhan pasar yang baru dan semakin meningkat (Hajiheydari, 2011). R\&D Mememberikan kontribusi yang penting kepada kinerja penjualan perusahaan, produktivitas dan profit (Heshmati dan Loof, 2008). Regel (2002) menyimpulkan bahwa terdapat hubungan positif antara pengeluaran R\&D dan penjualan, sera kinerja perusahaan.

Kurniawan dan Mertha (2016) menyampaikan bahwa tujuan R\&D adalah untuk menciptakan suatu produk baru atau mengembangkan produk lama menjadi lebih menarik dengan tujuan untuk meningkatkan minat konsumen yang akan berpengaruh pada peningkatan pendapatan. Keberhasilan sebuah R\&D telah memberikan keunggulan kompetitif bagi perusahaan karena dapat menjadi strategi didiferensiasi bagi perusahaan. Semakin tinggi kemampuan perusahaan dalam melaksanakan suatu $R \& D$, maka semakin tinggi tingkat kemampuan perusahaan untuk menciptakan dan menghasilkan produk dengan tingkat inovasi yang sesuai dengan konsumen (Darmawan et al, 2015).

Aktivitas R\&D yang sukses dapat menghasilkan produk atau jasa baru dan meningkatkan kualitas produk atau jasa yang ada (Zhu dan Huang, 2012). Produk-produk dengan kualitas yang tinggi dan unik telah disambut positif oleh pelanggan dipasar sehingga berdampak pada naiknya pendapatan perusahaan dan juga diiringi dengan meningkatnya kinerja keuangan perusahaan.

Aktivitas R\&D telah berhasil menciptakan sustainable product yang menyediakan manfaat lingkungan, sosial, dan ekonomi. Hal ini ditunjukkan pada laporan sustainability perusahaan dalam bentuk tanggung jawab produk yaitu untuk selalu menghadirkan produk berkualitas sesuai dengan standar kualitas produk sesuai dengan ketetapan regulator dan kebutuhan masyarakat, mementingkan kepuasan pelanggan, komitmen terhadap mutu mencakup seluruh kegiatan perusahaan mulai dari penelitian dan pengembagan, produksi, sampai dengan pemasaran. Penerapan produktifitas ramah lingkungan yang berorientasi pada kesejahteraan keluarga dan lingkungan. Dengan menciptakan produk yang ramah lingkungan dan menjaga kepuasan pelanggan perusahaan telah berhasil mencapai financial sustainability dengan tetap memperhatikan pilar sosial dan lingkungan.

Hal ini sesuai dengan teori RBV dan teori Institusional, kedua teori tersebut mendemonstrasikan pentingnya $R \& D$, manfaat sosial yang diperoleh dari aktivitas $R \& D$ dan bagaimana tindakan ini dirasakan oleh stakeholder, yang mungkin menciptaakan reputasi yang baik untuk perusahaan-perusahaan yang melakukan aktivitas R\&D (Padget dan Leite, 2012). Hail pengujian hipotesis kedua ditunjukkan pada Tabel 4. 
Tabel 4. Hasil Pengujian Koefisien Jalur Pengaruh Tidak Langsung (H2)

\begin{tabular}{|c|c|c|c|c|c|c|}
\hline \multicolumn{4}{|c|}{ Path Coefficient } & \multicolumn{3}{|c|}{$P$ values } \\
\hline & PRD & PFS & $\mathrm{MP}$ & PRD & PFS & MP \\
\hline PRD & & & & & & \\
\hline PFS & 0.02 & & 0.50 & 0.21 & & $<0.001$ \\
\hline MP & 0.12 & & & 0.02 & & \\
\hline
\end{tabular}

Hipotesis tiga menyatakan bahwa pengeluaran R\&D berpengaruh tidak lagsung terhadap financial sustaianability melalui gross margin. Hasil pengujian secara tidak langsung menunjukkan bahwa gross margin tidak mampu memediasi pengaruh pengeluaran $\mathrm{R} \& \mathrm{D}$ terhadap financial sustainability yang ditunjukkan dengan tidak signifikannya pengaruh langsung.

Hasil penelitian ini tidak mendukung penelitian terdahulu yang dilakukan oleh Dave et al (2013) yang memberikan bukti bahwa gross margin mampu memediasi hubungan pengeluaran R\&D terhadap financial sustainability. Namun dalam penelitian ini menemukan bukti bahwa pengeluaran $R \& D$ berpengaruh positif dan signifikan terhadap gross margin . Pengaruh positif antara pengeluaran R\&D terhadap gross margin menunjukkan bahwa aktivitas R\&D yang mengarah pada inovasi mampu meningkatkan gross margin perusahaan. Prosentase gross magin merupakan rasio laba kotor terhadap penjualan, dimana laba kotor merupakan penjualan dikurangi biaya pokok penjualan dan juga terdapat pengeluaran R\&D kotor. Sehingga diharapkan bahwa dengan meningkatnya $R \& D$ akan diiringi dengan meningkatnya laba kotor (Hall dan mairesse, 2009).

Penelitian ini juga memberikan temuan bahwa tingginya gross margin diiringi dengan rendahnya kemampuan perusahaan dalam meraih financial sustainability. Gross margin dihitung dengan melihat pendapatan dengan harga pokok yang dibutuhkan untuk produksi tanpa memasukkan unsur biaya seperti gaji, biaya pemasaran dan biaya administrasi. Biaya untuk menjalankan bisnis dibayarkan dari laba kotor dari penjualan produk. Jika perusahaan memiliki biaya lebih besar dibandingkan laba kotor, hasilnya adalah kerugian bisnis. Perusahaan dapat memiliki jumlah laba kotor yang besar, namun jika biaya untuk menjalankan bisnis lebih besar, maka perusahaan tidak akan mampu mendapatkan keuntungan. Hasil pengujian hipotesis tiga ditunjukkan pada tabel 5.

Hipotesis empat menyatakan bahwa pengeluaran R\&D berpengaruh tidak langsung terhadap financial sustaianbility melalui technological performance. Hasil pengujian secara tidak langsung menunjukkan bahwa technological performance tidak berperan sebagai pemediasi pengaruh pengeluaran R\&D terhadap financial sustaianbility.

Hasil penelitian ini tidak mendukung temuan yang telah dilakukan oleh Dave et al (2013) bahwa tingginya intensitas R\&D berpengaruh terhadap rendahnya technological performance dan tingginya technological performance berpengaruh terhadap tingginya kemampuan perusahaan dalam meraih financial sustainability. Temuan penelitian ini menunjukkan adanya hubungan positif antara pengeluaran R\&D terhadap technological performance. Hal ini menunjukkan bahwa dengan adanya aktivitas $R \& D$ telah mengarahkan perusahaan dalam penemuan teknologi baru yang mengarah pada peningkatan aset perusahaan. Ketika perusahaan mengembangkan teknologi baru, 
perusahaan mendaftarkan teknologi tersebut sebagai hak paten, dimana hak paten ini merupakan bagian dari aset tak berwujud perusahaan (Dave et al, 2013). Lee dan You (2016) menyampaikan bahwa kemampuan perusahaan untuk melakukan R\&D dan strategi terkait memiliki pengaruh signifikan pada technological performance. Kompetensi berbasis penelitian memainkan peran yang semakin pentng dalam pengembangan inovasi dan teknologi baru ( Lennart, 2014)

Temuan lainnya adalah technological performance berpengaruh negatif terhadap financial sustainability. Technological performance diukur dengan menggunakan non current asset turnover. Non current asset turnover ratio menentukan efisiensi dimana bisnis menggunakan aset tidak lancar untuk menghasilkan pendapatan bagi bisnis. Aset tidak lancar tidak dapat dikonversi menjadi uang selama tahun menjalankan bisnis. Aset tidak lancar merupakan pencipta pendapatan yang lebih dibandingkan aset lancar namun keterlibatan resiko lebih dari aset lancar dikarenakan sulitnya untuk dikonversikan ke uang tunai dan nilainya juga berbeda dalam waktu yang berbeda dibandingkan aset lancar (Iqbal dan Mati, 2012). Cyril dan Ogbonna (2013) menyampaikan jika properti, tanah, dan peralatan menganggur atau tidak cukup menghasilkan arus kas, maka akan berdampak pada nilai dan kesehatan keuangan bisnis. Hal ini menunjukkan bahwa peningkatan aset perusahaan sampel tidak banyak memberikan kontribusi pada kenaikan pendapatan perusahaan. Hasil pengujian hipotesis empat ditunjukkan pada Tabel 5.

Tabel 5. Hasil Pengujian Koefisien Jalur Pengaruh Tidak Langsung (H3,H4)

\begin{tabular}{|c|c|c|c|c|c|c|c|}
\hline \multicolumn{5}{|c|}{ Path Coefficient } & \multicolumn{3}{|c|}{$\mathrm{P}$ values } \\
\hline IRD & IRD & FSR & GM & $\mathrm{TP}$ & IRD & GM & $\mathrm{TP}$ \\
\hline FSR & -0.22 & & -0.66 & -0.13 & 0.9995 & 0.9995 & 0.998 \\
\hline GM & 0.46 & & & & $<0.001$ & & \\
\hline TP & 0.48 & & & & $<0.001$ & & \\
\hline
\end{tabular}

\section{PENUTUP}

Penelitian ini bertujuan untuk menguji dan menganalisis pengaruh pengeluaran R\&D terhadap financial sustainability dengan marketing performance, gross margin, dan technological performance sebagai pemediasi. Penelitian ini dilakukan pada perusahaan manufaktur yang terdaftar di BEI pada tahunn 2007 hingga 2016 dengan menggunakan 13 perusahaan dan total 130 sampel.

Penelitian ini menemukan bahwa semakin tinggi pertumbuhan R\&D sebuah perusahaan akan meningkatkan pertumbuhan penjualan/pendapatan perusahaan, dengan meningkatnya pendapatan perusahaan akan berdampak pada tingginya kemampuan perusahaan untuk dapat meraih financial sustainability. Aktivitas R\&D telah berhasil menciptakan produk-produk atau jasa baru dan juga meningkatkan kualitas dari produk atau jasa yang sudah ada. Produk-produk atau jasa tersebut telah disambut dengan positif oleh pelanggan. Selain itu aktivitas R\&D Telah berhasil menciptakan sustainable product, dimana sustainable product merupakan produk yang menyediakan manfaat lingkungan, sosial dan ekonomi sekaligus melindungi kesehatan masyarakat dan lingkungan selama siklus hidupnya, mulai dari ekstraksi bahan mentah hingga 
pembuangan akhir. Produk-produk dengan kualitas yang tinggi telah disambut positif oleh pelanggan dipasar, sehingga berdampak pada naiknya pendapatan perusahaan dan juga diiringi dengan meningkatnya kinerja keuangan perusahaan. Menurut Doane dan Mac Gilivray (2001) menyampaikan bahwa perusahaan-perusahaan yang dapat secara efektif mengelola lingkungan dan sosial mereka juga akan membantu perusahaan berkelanjutan secara eonomi. Dengan adanya produk-produk yang memberikan manfaat lingkungan dan meraih financial sustainability.

Temuan ini sesuai dengan konsep dari teori Resource Based View dan teori institusional. Kedua teori mendemonstrasikan pentingnya $R \& D$, manfaat sosial yang diperoleh dari aktivitas R\&D dan bagaimana tindakan ini dirasakan oleh stakeholder, yang mungkin menciptaakan reputasi yang baik untuk perusahaan-perusahaan yang melakukan aktivitas R\&D (Padget dan Leite, 2012).

Hasil penelitian ini juga menemukan bahwa gross margin dan technological performmance tidak mampu menjadi pemediasi dalam hubungan pengeluaran $\mathrm{R} \& \mathrm{D}$ terhadap financial sustainability. Tingginya intensitas R\&D memberikan dampak pada tingginya gross margin perusahaan, namun tidak memberikan dampak pada pencapaian financial sustainability perusahaan. Tingginya gross margin perusahaan yang diiringi dengan tingginya biaya penjualan, pemasaran, dan administrasi dan umum maka perusahaan tidak akan mampu mendapatkan keuntungan.

Tingginya intensitas R\&D juga memberikan dampak pada tingginya technological perfromance perusahaan yang diukur dengan menggunakan non current asset turnover, namun tidak memberikan dampak

pada kemampuan perusahaan dalam meraih financial sustainability. Jika Properti, tanah, dan peralatan menganggur atau tidak cukup menghasilkan arus kas, maka akan berdampak pada nilai dan kesehatan keuangan bisnis (Cyril dan Ogbonna, 2013). Hal ini menunjukkan bahwa peningkatan aset perusahaan sampel tidak banyak memberikan kontribusi pada kenaikan pendapatan perusahaan

Penelitian ini memiliki keterbatasan. Sampel penelitian ini menggunakan seluruh perusahaan manufaktur yang terdaftar di BEI. Namun dikarenakan kriteria yang ditetapkan pada penelitian ini, hanya didapatkan 13 perusahaan manufaktur yang memenuhi. Penelitian selanjutnya diharapkan dapat meningkatkan jumlah sampel yang diteliti dengan melibatkan seluruh perusahaaan yang terdaftar di BEI.

Masih jarangnya penelitian terdahulu yang mengeksplorasi hubungan $R \& D$ terhadap financial sustainability sehingga penelitian ini mengeksplorasi hubungan tersebut yang sangat bermanfaat bagi penunjang hasil literatur bidang akuntasi keuangan. Sehingga masih perlu lebih banyaknya dieksplorasi penelitian di bidang financial sustainability.

Penelitian ini fokus hanya pada financial sustainability saja. Kedua pilar sustainability lainnya yaitu social dan environment tidak dieksplor dalam penelitian ini karena keterbatasan data yang diperoleh peneliti. Penelitian kedepannya dapat memasukkan pilar social dan environment sustainability. Sehingga penelitian mengenai sustainability lebih menyeluruh.

\section{DAFTAR RUJUKAN}


Abdillah W dan Hartono J. (2015). Partial Least Square (PLS) Alternatif Structural Equation Modeling (SEM) dalam Penelitian Bisnis. ANDI Yogyakarta

Adams M, Thornton B, and Sepehri M.( 2010). "The Impact of the Pursuit os Sustainability on the Financial Performance of the Firm". Journal of Sustainability and Green Business

Adams W.M. (2006). The Future of Sustainability: Re-thinking Environment and Development in the Twenty-first Century. Report of the IUCN Renowned Thinkers Meeting.

Atalay M, Anafarta N, Sarvan F. (2013). “The Relationship between Innovation and Firm Performance: An empirical evidence from Turkish Automotive Supplier Industry". Procedia - Social and Behavioral Sciences, 75, 225-235.

Barney J. (1991). "Firm Resources and Sustained Competitive Advantage". Journal of Management, 17(1), 99-120.

Basgoze P dan H. C. Sayin. (2013). "The Effect of R\&D Expenditure (Investments) on Firm Value: Case of Istanbul Stock Exchange". Journal of Business Economics \& Finance, 2(3).

Berrone P, Gelabert L, Fosfuri A, Mejia. (2007). Can Institutional Forces Create Competitive Advantage? Empirical Examination of Environmental Innovation. IESE Business School. University of Navarra

Bouaziz Z. (2014). "The Impact of R\&D Expenses on Firm Performance: Empirical Witness from the Bist Technology Index". Journal of Business Theory and Practice, 4(1).

Chang Hao-Shu, Chen Ho-Chia, dan Ho Ching Yu. (2012). "A Study of Marketing Performance Evaluation System for Notebook Distributors”. International Journal of Business and Management, 7(13).

Crepon B, Duguet E, Mairese J. (1998). "Research, Innovation, and Productivity: An Econometric Analysis at the Firm Level". National Bureau of Economic Research. Working Paper 6696

Cyril Madubuko U dan Ogbonna Eunice E. (2013). Evaluation of the Effect of NonCureent Assets on Return on Assets of Cement Manufacturing Industry in Nigeria

Darmawan A, Suharyono, Iqbal M. (2015). "Pengaruh R\&D Expenditure terhadap Penjualan (Studi kasus Pada Nissan Motor Company Ltd)". Fakultas ilmu Administrasi. Universitas Brawijaya. Jurnal Administrasi Bisnis, 2(2).

Dave P, Wadhwa V, Aggarwal S, Seetharaman A. (2013). "The Impact and Development on the Financial Sustainability of Information Technology (IT) Companies Listed on the S\&P 500 Index". Journal of Sustainable Development, 6(11), 122138.

DiMaggio P, dan Powell W. (1983). "The Iron Cage Revisited: Institutional Isomorphism and Collective Rationality in Organizational Fields". American Sociological Review, 48(2), 147-160.

Doane D and MacGilivray A. (2001). Economic Sustainability The Business of Staying in Business.R\&D Report. The Sigma Project.

Grant R.M. (1991). "The Resource-Based Theory of Competitive Advantage: Implications for Strateg Formulation". California Management Review, Spring: 114-135. 
Hajiheydari A, Dastgir M, Soltani A. (2011). "The Effect of Research and Development Costs on the Profitability of Pharmaceutical Companies". Interdiciplinary Journal of Contemporary Research of Business, 3(8), 914-918.

Hall H, Lotti F, dan Mairesse. (2012). Evidence on the Impact of R\&D and ICT Investments on Innovation and Productivity in Italian Firms. Economics of Innovation and New Technology, 1-24.

Hall H, Foray D, Mairesse. (2009). Pitfalls in Estimating the Returns to Corporate R\&D Using Accounting Data.

Hall H, Mairesse J, Mohnen P. (2009). Measuring the Return to R\&D. National Bureau of Economic Research. NBER working paper No. 15622

Hsu Jui F, Chen Yen M, Chen Cheng Y, and wang Chieh w. (2013). "An Empirical Study on the Relationship between R\&D and Financial Performance". Journal of Applied Finance \& Banking, 3(5), 107-119.

Indriantoro N dan Supomo M. (2016). Metodologi Penelitian Bisnis Untuk Akuntansi \& Manajemen, Edisi Pertama. BPFE Yogyakarta

Iqbal A dan Mati M. (2012). Relationship Between Non-Current Assets \& Firms Profitability. MPRA Paper No. 44132, 101-111.

Jagelavicius G. (2013). "Gross Margin Management Framework for Merchandising Decision in Companies with Large Assortment of Products". Journal Economics and Management, 18(1), 6-16.

Jeruzelski B, Dehoff K, dan Bordia R. (2006). Smart Spenders: The Global Innovation 1000.

Konak F, Kendirli S. (2014). The Impact of R\&D Expenses on Firm Performance: Empirical Evidence from the BIST Information Technology Index. Economic Science and Business Administration (CESBA), 192-197.

Kurniawan Prawira A dan Mertha I Made. (2016). "Kinerja Keungan Sebagai Pemediasi pengaruh Intensitas research and Development dan Aset Tidak Berwujud Pada Nilai Perusahaan". E-Jurnal Akuntansi Universitas Udayana, 14(1), 723-750

Lantz Sebatian J, Sahut Michael J. (2005). "R\&D Investment and the Financial Performance of Technological Firms". International Journal of Business, 10(3), 251-270.

Lee Chang J and You Yen Y. (2016). "Effects of Corporate Technological Innovation Activities on Technological and Management Perfromance - Focusing on Government Supported Conergence Consulting”. Indian Journal of Science and Technology, 9(41).

Leon P. (2001). Four Pillars of Financial Sustainability. International Publications Program. The Nature Concervacy. Resources for Succes Series Volume 2.

Listyarso A. (2005). "Pengaruh Strategi Pemasaran Terhadap Kinerja Pemasaran dan Kinerja Perusahaan dengan Lingkungan Persaingan Sebagai Variabel Moderating”. Tesis. Universitas Diponegoro Malang.

Oliver C. (1991). "Strategic Responses to Intitutional Processes". Academy of Management Review, 16(1), 145-179.

Padgett Carlton R, Leite Moura C. (2012). "The Impact of R\&D Intensity on Corporate Reputation: Interaction Effect of Innovation with High Social benefit". Intangible Capital, 8(2), 216-238. 
Prihadyanti D, Laksani S.C. (2015). "R\&D dan Inovasi di perusahaan Sektor Manufaktur Indonesia”. Jurnal Manajemen Teknologi, 14(2), 187-198.

Quevedo-Puente, E.; Fuente-Sabaté, J.M.; Delgado-García, J.B. (2007). "Corporate socialperformance and corporate reputation: Two interwoven perspectives". Corporate Reputation Review, 10(1).

Regel C.C. (2002). Research Development Intensity and Firm Performance, technology Management: The New Intenational Language.

Roberts P.W, Dowling G.R. (2002). "Corporate Reputation ans Sustained Superior Financial Performance”. Strategic Management Journal, 23, 1077-1093.

Sherer, P.D. dan Lee K. (2002). "Institutional Change in Larg Law Companies: A Resource Dependency and Institutional Perspective". Academy of management journal, 43(1), 102-119.

Wang Hung C. (2011). "Clarifying The effects of R\&D on Performance: Evidence from The High Technology Industries". Asia Pacific Management review, 16(1), 51-64.

Zhu Zhaouhui, Huang Feng. (2012). The Effect of R\&D Investment on Firms Financial Performance: Evidence from the Chinese Listed IT firms. Scientific Research. 
Wardana, Hariadi dan Saraswati: Pengeluaran R \& D dan Financial Sustainability... 